\title{
Applying a SERVQUAL Model to Measure the Impact of Service Quality on Customer Loyalty among Local Saudi Banks in Riyadh
}

\author{
Abbas N. Albarq \\ School of Economics \& Administrative Science, Al Imam ibn Muhammad ibn Saud Islamic University, Riyadh, KSA. \\ Email: dr.abbasalbarq@yahoo.com \\ Received October $3^{\text {rd }}, 2013$; revised November $3^{\text {rd }}, 2013$; accepted November $11^{\text {th }}, 2013$ \\ Copyright (C 2013 Abbas N. Albarq. This is an open access article distributed under the Creative Commons Attribution License, \\ which permits unrestricted use, distribution, and reproduction in any medium, provided the original work is properly cited. In accor- \\ dance of the Creative Commons Attribution License all Copyrights @ 2013 are reserved for SCIRP and the owner of the intellectual \\ property Abbas N. Albarq. All Copyright @ 2013 are guarded by law and by SCIRP as a guardian.
}

\begin{abstract}
This paper evaluates the impact of service quality underlying the SERVQUAL model on customer loyalty, with customer satisfaction mediating these variables. This analytical study is mainly based on the primary data collected through a questionnaire that was personally administered to 422 individuals selected from five local banks in Riyadh, Saudi Arabia. The findings indicate that improving service quality can help to enhance customer loyalty. Empathy, assurance, and reliability are the service quality dimensions that play significant roles in this equation. The study's findings indicate that while the respondents evaluate the banks positively overall, there is still room for improvement. Few studies have assessed customer loyalty in Saudi banking. Increased competition between banks means that service quality is increasingly important and bank managers should consider how they can improve customer satisfaction with respect to service quality in order to enhance customer loyalty.
\end{abstract}

Keywords: SERVQUAL; Customer Satisfaction; Customer Loyalty; Local Saudi Banks

\section{Introduction}

The Saudi banking sector is becoming increasingly competitive and consolidated, which means that local banks are facing shareholder pressure to focus on value rather than revenue growth. The ease and convenience offered by technologies such as mobile phones and the internet have helped Saudi financial institutions serve the domestic economy and their customers. Banks are now facing strong and intense competition [1]. Banks in Saudi Arabia are formulating various strategies to retain customers, the key to which is increasing service loyalty levels. Around the world, customer loyalty (that is, customer retention) generally has a strong link to the firm's profitability and long-term growth [2]. In the context of banking services, small increases in customer retention rates can increase profits dramatically [3]. Saudi banks need a system to foster customer loyalty.

The roots of Saudi Arabia's current banking system date back to October 1952, when the Saudi Arabian
Monetary Agency [4] was created and given primary responsibility for monetary stability. Before the SAMA was established, branches of a few foreign banks, along with some local money changers, provided financial services to the trading community and pilgrims. By 1952, royalties from production and demand for oil had combined to create a significant increase in government revenues and expenditures, which led to a sharp rise in demand for financial services [5]. Along with systematic stability and sustained growth, one of the Saudi government's main policies encouraged a healthy competitive environment that enables consumers to efficiently and cost-effectively access a broad range of financial and banking services. This focus of service and choice has resulted in a number of policy decisions over the last 50 years or so. The resulting competition is especially noticeable in the corporate and private banking sectors, where customers are able to choose from a range of domestic and international financial institutions and banks. In such a competitive environment, banks must plan 
strategies to differentiate themselves from each other. One way to achieve this is by delivering high service quality. Reference [5] has shown that customer satisfaction leads to customer loyalty.

A service provider's success depends on whether it has a high-quality relationship with its customers [6], which, in turn, helps determine customer loyalty [7]. Several studies have shown that service quality has an influence on organizational outcomes such as performance superiority, which increases sales profits [8-10], and market share [11], which improves customer relations, enhances the company's corporate image, and promotes customer loyalty [12]. Furthermore, studies have also found customer satisfaction and service quality to be related to customer loyalty through repurchase intentions $[8,12]$.

A review of the literature reveals that no research has yet applied the SERVQUAL model to customer loyalty in a developing country such as Saudi Arabia. Understanding the impact of service quality underlying the SERVQUAL model on customer loyalty can help bank managers to focus their efforts on the key areas that contribute most to increasing customer retention. From an academic perspective, therefore, the present study offers insights that will improve the understanding of the impact that various factors related to e-commerce customer loyalty have in the context of Saudi Arabia, a major developing country in the Middle East. Previous studies [1] have identified the need to examine customer loyalty toward banks from the perspective of a less developed country. Furthermore, not only is there a shortage of data on service quality and customer loyalty in banking in developing countries, but most of the models that measure service quality have been created in developed countries such as the United States [13]. A sentiment shared by [1], who stated that culture can also influence the outcomes of the research and went further asking questioned how valid it is to apply the findings of research from developed countries to less developed countries; Care must be taken when extending the findings of studies conducted in developed countries to less-developed countries, such as Saudi Arabia.

\section{Literature Review}

\subsection{Customer Loyalty}

Loyalty is developed over a period of time based on consistently meeting or exceeding customer expectations [14]. Reference [15] estimated that the cost of attracting a new customer may be up to five times greater than the cost of retaining a happy customer. The definition of customer loyalty that [16] offered relates to the purpose of the present study: the degree to which a customer exhibits repeat purchase behavior from a service provider, has a positive attitude toward the provider, and considers using only this provider when they have a need for the service that the provider offers. According to [16] true loyalty is different from repeat purchasing behavior, which is the actual re-buying of a brand, regardless of commitment. Reference [17] stated that although loyalty is a multi-dimensional construct that includes both positive and negative responses, a loyal customer is not necessarily a satisfied customer. Reference [4] noted that customer defection is not always the inverse of loyalty, while [8] suggested that, "even if a problem is not solved, approximately half of the customers would remain with the firm”. This reluctance or inability to change companies could be due to switching costs, a lack of perceived differentiation of alternatives, constraints regarding location, time, or money, or habits or inertia that are unrelated to loyalty $[18,19]$.

\subsection{Service Quality}

Based on the existing definitions, service quality is the result of customers' comparison between their expectations of a service and their perception of how well the service has been performed [5,13,20-22]. Reference [13] defined service quality as the discrepancy between customers' normative expectation for service and their perceptions of service performance. Reference [13] later developed the definition of service quality as "the overall evaluation of a specific service firm that results from comparing that firm's performance with the customer's general expectations of how firms in that industry should perform."

Reference [23] study revealed that perceived service quality is strongly related to loyalty, which influences customers to continue using a particular bank and recommend it to others. However, [23] findings that service quality affects customer satisfaction loyalty have been shown to be inconclusive, as many customers change to other banks due to low switching costs. A study [11] concluded that perceived service quality in terms of the efficiency of service delivery is a crucial factor for banking loyalty. However, that study failed to indicate which criteria are most important to customers in terms of customer satisfaction and loyalty. Reference [5] argued that customer satisfaction performs a mediating role between service and customer loyalty. Reference [24] found that the potential determinants of customer loyalty are the dimensions of the service quality. In both of the two above-mentioned studies, however, the service quality only has an impact on customer satisfaction of approximately 50 percent, which has been found to be inconclusive as other factors appear to be equally important for the delivery of satisfaction and loyalty.

Since the early 1990s, organizations in developed 
countries have adopted quality concepts such as total quality management (TQM) and new public management (NPM). For example, the main objective of NPM is to take a customer-oriented approach to improve service quality delivery. Reference [25] Integrated data envelopment analysis (DEA) and neural network (NNs) to examine relative branch efficiency. The DEA technique has been used for performance benchmarking of bank branches in terms of operating efficiency (service quality) and profitability [26]. The most popular model for evaluating service quality is SERVQUAL, which was developed by [13] and has the attributes of tangibility, competency, courtesy, reliability, responsiveness, credibility, access, assurance, security, and understanding. Reference [13] later used a factor analysis to reduce these $10 \mathrm{di}-$ mensions to five.

The five dimensions are: 1) Tangibles - the physical facilities, equipment, and staff appearance; 2) Reliability-The ability to perform the promised service dependably and accurately; 3) Responsiveness - the willingness to provide prompt service and help to customers. 4) Assurance (which includes competence, courtesy, credibility, and security) — the knowledge and courtesy of employees, plus their ability to inspire trust and confidence; and 5) Empathy (including access, communication, and understanding the customer) — the caring and individualized attention that the firm provides to its customers.

Although the SERVQUAL instrument has attracted some criticism [27], it remains the most commonly utilized instrument for its confirmatory factor analyses. To date, SERVQUAL has proven to be a parsimonious model used in various service organizations and Industries, including banks, to measure service quality $[5,7$, 8,28-32].

\subsection{Customer Satisfaction}

Perceived service quality is a global judgment or attitude that relates to the superiority of the service, whereas satisfaction refers to a specific transaction [13]. Customer satisfaction has commonly been described as the leading determinant of loyalty [23]. Reference [12] argued that customer satisfaction is significantly positively related to customer loyalty/retention. In the present study, therefore, customer satisfaction acts as a mediator between service quality and customer loyalty.

\subsection{Customer Satisfaction and Loyalty}

The service management and marketing literatures agree that there is a strong theoretical foundation for empirically exploring the linkages between customer satisfaction and customer loyalty. For example, [33] argued that there is a strong and positive relationship between cus- tomer satisfaction and loyalty. Satisfied customers are six times more likely to repurchase a product and share their experience with five or six other people [22,34], while an unsatisfied customer can turn more business away from an organization than 10 highly satisfied customers would turn towards it [35]. The results of [36] study indicated a significant positive relationship between customer satisfaction and customer loyalty, while several other studies have also found satisfaction to be a leading factor in determining loyalty [37]. The conclusion that these studies have reached is that a high level of customer satisfaction will lead to increased loyalty to the firm and has a positive association with repurchase intentions, positive word of mouth, and profitability. Based on the above empirical literature, customer satisfaction has been identified as a leading determinant of customer loyalty.

\section{Research Theoretical Model}

Figure 1, which has been adapted from [38], depicts the theoretical model that guides the present study. As the framework shows, the present study examines the relationships between tangibles, reliability, responsiveness, assurance, empathy with customer satisfaction, and customer loyalty.

\section{Hypotheses Development}

The present study aims to determine the factors that affect customer loyalty in the banking industry in order to help create a loyalty model for banking customers. With this in mind, we have formulated the following hypotheses:

H1a: Tangibles have a significant positive impact toward customer loyalty.

H1b: Tangibles have a significant positive impact on customer satisfaction toward customer loyalty.

H2a: Reliability has a significant positive impact toward customer loyalty.

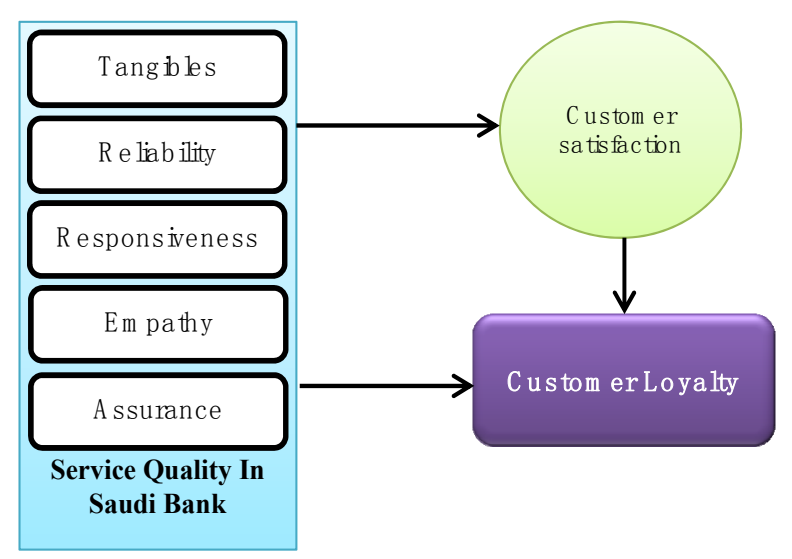

Figure 1. Research hypothesized model. 
H2b: Reliability has a significant positive impact on customer satisfaction toward customer loyalty.

H3a: Responsiveness has a significant positive impact toward customer loyalty.

H3b: Responsiveness has significant positive impact on customer satisfaction toward customer loyalty.

H4a: Empathy has a significant positive impact toward customer loyalty.

H4b: Empathy has a significant positive impact on customer satisfaction toward customer loyalty.

H5a: Assurance will have a positive effect toward customer loyalty.

H5b: Assurance has a significant positive impact on customer satisfaction toward customer loyalty.

H6a: Customer satisfaction is a mediator between service quality in Saud bank and customer quality.

H6b: Customer satisfaction has a significant positive impact on customer loyalty.

\section{Method}

To test the above hypotheses, we conducted a survey of customers of several local banks in Riyadh, the capital of Saudi Arabia. Conducting the survey involved certain challenges, especially in terms of how to design the sampling procedures, given that it is not legally or socially permitted for male strangers to approach females in Saudi Arabia. Accordingly, we used a convenience sample. The questionnaires were self-administered, meaning that instead of an interviewer asking the questions of the respondents, the respondents themselves read and answered the questionnaire. We also had female assistances to help us distribute the questionnaires to the females. In Saudi Arabia, all banks must have one section for males and another for female. Participation in the study was voluntary and limited to customers who had at least one bank account.

The fact that the survey was conducted in Saudi Arabia meant it was necessary to translate the questionnaire from English to Arabic and ensure that both versions used equivalent language. Two bilingual Arabic/English lecturers at the $\mathrm{Al}$ Imam Language Center translated the questionnaire into Arabic. We used the double-translation method to avoid confusion or misinterpretation and to ensure that the Arabic version accurately represented the English version [39].

We adapted SERVQUAL for measuring service quality and adopted the customer loyalty measurement from [5]. For the measurement, we used a seven-point Likert scale, ranging from 1 (strongly disagree) to 7 (strongly agree). The questionnaire included questions about the respondents' demographic profile, as well as items to measure the constructs. The questionnaires were pretested with 10 selected customers who had experience with banking at their branch. The respondents were requested to provide feedback about the clarity and structure of the questions. Based partly on the pre-test, we refined the original questions and made some other changes to the questionnaire. The self-administered questionnaire was then used to gather data from a total of 422 bank customers.

\section{Results}

Table 1 shows the results obtained after the recorded demographic variables were analyzed using descriptive statistics. The frequency and percentage for each variable is listed according to the survey categories in this table.

In Table 2, the frequency distribution for banking transactions per month, the most common channels used for carrying out banking transactions were Internet banking with 233 respondents (55.2 percent), ATMs (114, 27.0 percent), telephone banking (18, 4.3 percent), and branch banking (57, 13.5 percent). See Table 2 for more details. We assessed the reliability of the measures using the inter-item consistency measure of Cronbach's alpha.

The alpha for all the independent variables and the dependent variable ranged from 0.988 to 0.941 , which exceeds the minimum acceptable value of 0.70 [40]; accordingly, no items were deleted. Assurance was the variable with the highest standard deviation (1.59), followed by customer satisfaction, empathy, tangibility, reliability, and responsiveness (1.14). The fact that there are only small differences in standard deviation for all

Table 1. Personal profile of respondents $(N=422)$.

\begin{tabular}{|c|c|c|c|}
\hline Profile & Description & $\begin{array}{c}\text { Number of } \\
\text { Respondents }\end{array}$ & (\%) \\
\hline \multirow{4}{*}{ Age } & $18-29$ & 165 & 39.0 \\
\hline & $30-39$ & 119 & 28.2 \\
\hline & $40-49$ & 96 & 22.7 \\
\hline & 50 and above & 42 & 10.1 \\
\hline \multirow{2}{*}{ Gender } & Male & 243 & 57.9 \\
\hline & Female & 179 & 42.1 \\
\hline \multirow{4}{*}{$\begin{array}{c}\text { Education } \\
\text { Level }\end{array}$} & High school & 141 & 33.4 \\
\hline & Bachelor Degree & 178 & 42.2 \\
\hline & Master's Degree & 71 & 16.8 \\
\hline & Doctoral Degree & 32 & 7.6 \\
\hline \multirow{4}{*}{$\begin{array}{l}\text { Income per } \\
\text { month }\end{array}$} & Less than 5000 SAR & 80 & 18.5 \\
\hline & $5000-10,000$ SAR & 131 & 31.0 \\
\hline & 10001 - 15,000 SAR & 143 & 33.9 \\
\hline & 15,001 SAR and over & 68 & 16.6 \\
\hline
\end{tabular}


Table 2. Frequency distribution for banking transactions per month.

\begin{tabular}{|c|c|c|c|}
\hline Variable & Instruments & Frequency & $(\%)$ \\
\hline \multirow{4}{*}{$\begin{array}{l}\text { Number of times } \\
\text { bank used per } \\
\text { month }\end{array}$} & 1 time & 42 & 9.9 \\
\hline & 2 & 114 & 27.0 \\
\hline & 3 & 119 & 28.2 \\
\hline & 4 & 96 & 22.7 \\
\hline \multirow{6}{*}{$\begin{array}{c}\text { Type of accounts } \\
\text { used }\end{array}$} & More than 4 times & 51 & 12.2 \\
\hline & Savings account & 188 & 44.5 \\
\hline & Current account & 101 & 23.9 \\
\hline & Personal loans & 91 & 21.6 \\
\hline & Mortgage & 38 & 9.0 \\
\hline & Others & 4 & 1.0 \\
\hline \multirow{5}{*}{$\begin{array}{c}\text { Type of channels } \\
\text { used } \\
\text { to carry out } \\
\text { banking } \\
\text { transactions }\end{array}$} & Branch banking & 57 & 13.5 \\
\hline & ATM & 114 & 27.0 \\
\hline & Internet banking & 233 & 55.2 \\
\hline & Phone banking & 18 & 4.3 \\
\hline & Other & - & - \\
\hline
\end{tabular}

variables indicates that respondents are consistent in their evaluation (see Table 3).

We conducted the regression tests in the manner suggested by [41], in the four following separate analysis steps: Step 1 analyzed customer loyalty as the dependent variable and dimensions of service quality as the independent variables. Step 2 examined customer satisfaction as the dependent variable and dimensions of service quality as the independent variables In Steps 3 and 4, customer loyalty was the dependent variable and customer satisfaction, together with dimensions of service quality, were the independent variables.

As Table 4 shows, Tangibles (IV) was found to be non-significant against Customer Loyalty (DV), which means that no mediation occurs.

\section{Discussion}

The regression analysis revealed that tangible factors have no significant impact on customer loyalty, a finding that contradicts those of [30]. We observed a changing trend, and respondents no longer treated tangibility as an important measurement due to the availability of selfservice terminals. This suggests that Saudi banks must look into upgrading the proficiency of their self-service terminals rather than upgrading the interiors of the branches. Also, the emergence of technology has led to tangibles losing its importance as a measurement of cus-
Table 3. Reliability coefficient, mean, and standard deviation (SD) for the major variables.

\begin{tabular}{ccccc}
\hline Variables & $\begin{array}{c}\text { Number } \\
\text { of items }\end{array}$ & $\begin{array}{c}\text { Cronbach's } \\
\text { Alpha }\end{array}$ & Mean & S.D \\
\hline Tangibles & 5 & 0.941 & 5.32 & 1.29 \\
Reliability & 4 & 0.967 & 5.32 & 1.31 \\
Responsiveness & 3 & 0.938 & 4.92 & 1.14 \\
Empathy & 4 & 0.944 & 4.81 & 1.40 \\
Assurance & 3 & 0.988 & 5.00 & 1.59 \\
Customer satisfaction & 3 & 0.988 & 5.77 & 1.49 \\
Customer loyalty & 4 & 0.961 & 5.62 & 1.58 \\
\hline
\end{tabular}

Table 4. Results of multiple regressions.

\begin{tabular}{cccc}
\hline & Step 1 & Step 2 & Step 3 + Step 4 \\
\hline DV. & Loyalty & Satisfaction & Loyalty \\
\hline IVs. & \multicolumn{3}{c}{ Standardized coefficients $-\boldsymbol{\beta}$} \\
\hline Tangibles & 0.06 & 0.9 & 0.01 \\
Reliability & $0.24^{* *}$ & -0.05 & $0.28^{* *}$ \\
Responsiveness & 0.01 & $0.14^{* *}$ & -0.07 \\
Empathy & $0.28^{* *}$ & $0.24^{* *}$ & $0.014^{*}$ Partially mediated \\
Assurance & $0.37^{* *}$ & $0.41^{* *}$ & 0.03 Fully mediated \\
Satisfaction & & & $0.65^{* *}$ \\
Steps summary & Step 1 & Step 2 & Step 3 + Step 4 \\
R 2 & 0.797 & 0.841 & 0.859 \\
Adjusted R 2 & 0.791 & 0.831 & 0.855 \\
Durbin Watson & 2.18 & 1.49 & 1.89 \\
F value & $188.42^{* *}$ & $241.61^{* *}$ & $239.49^{* *}$ \\
\hline
\end{tabular}

${ }^{* *} \mathrm{p}<0.01,{ }^{*} \mathrm{p}<0.05$.

tomer loyalty. Internet banking has become extremely popular among Saudi bank customers. Technology developments and innovations have had a significant impact on the banking business. For example, there were estimated to be approximately 7.5 million foreign workers in Saudi Arabia as of April 2013 [3]. Most of these workers travel back to their home countries at least once a year and need to use their bank accounts overseas. Saudi banks should consider IT issues such as this and use IT as a measurement for customer loyalty; this will provide a better reflection of the current banking environment. Our study also found that tangibles were not significant as a mediating variable (customer satisfaction) and bank customers do not view tangibility as an important factor. 
We found that reliability had a positive relationship with customer loyalty, a finding that supports previous studies such as $[42,43]$. However, reliability was found to be non-significant for customer satisfaction. This is in line with the finding that customers may remain with a company even if they are dissatisfied because they feel they have no choice. Surprisingly, our finding the relationship between responsiveness and customer loyalty to be insignificant is contrary to findings of other studies [44-47]. Customer loyalty remains an important factor that banks must take seriously. Bank customers are being increasingly more educated and knowledgeable, and their demands are also increasing; therefore, banks must improve their customer service. Loyalty programs are one way to retain customers.

The arrival of foreign banks in Saudi Arabia has meant that local banks must improve their service quality. Results from the present study's hypotheses testing also show that responsiveness has a positive relationship with customer satisfaction. This finding is in keeping with that of [47], who noted that perceptions of service quality were enhanced by the speed of service delivery, and [46], who found that the absence of waiting time increased the satisfaction levels of customers.

Our finding that empathy has a significant positive relationship with customer loyalty is supported by the findings of $[12,48,49]$. Reference [48] argued, the existence of friendship between customers and certain service employees can have a significant influence on customer loyalty. According to reference [49], companies can achieve customer satisfaction by offering personalized, flexible, and adjustable services. The present study reached a similar conclusion, finding that empathy has a positive impact on customer satisfaction.

The present study has shown a significant relationship between assurance and customer loyalty and is consistent with previous studies, including [7,19]. The present study found assurance to be a significant prediction of customer satisfaction, which is in line with [49] argument that communication is a strong indicator of overall satisfaction and an important source of customer satisfaction in the Malaysian banking sector. The present study also found that satisfaction has a mediating effect on the relationships between service quality dimensions (tangibility, reliability, responsiveness, empathy, and assurance) and customer loyalty. This result is in line with $[5,23,48]$.

In terms of legislation, the Banking and Financial Act 2000 governs the conduct of banks in Saudi Arabia. Although this legislation stipulates that customer's information must not be divulged to third parties without the customers' consent, customer information is being sold, especially to banks' marketing departments. Marketers of credit, loan, and insurance products obtain customers' information from various sources and then make calls to customers to market their products. The banking Industry's outsourcing of some of its departments will create further potential for customer information to be divulged without permission. This is an area for Saudi Banks to investigate because customers will not be happy to learn that their information has been sold to third parties without their consent. The present study shows that respondents evaluate Saudi bank positively overall, with every variable having a mean above 4.00 (see Table 3). However, there is still room for improvement.

The main managerial implication of this study is that bank managers require effective recruitment and training programs in order to ensure that their employees offer professional services, pay greater attention to customer needs, and avoid revealing customer information to third parties.

\section{Conclusion}

Banks must continue to address customer service in order to meet the changes in the banking industry. Future research should incorporate new technologies as a factor with which to measure service quality. Studies and related questionnaires must also accommodate the new banking requirements of the customer. Having a clearer understanding of the relationship between service quality, customer loyalty, and customer satisfaction can help ensure better targeting of customers using limited marketing resources.

\section{Limitations}

This study has certain limitation. Firstly, we did not consider control variables of socio-demographic variables. [5] found education and age to be salient segmentation variables. Secondly, all of the questionnaires were administered to respondents in Riyadh City, therefore, future studies can be conducted to a wider population or bank customers, as well as cultural issues, should be taken with caution.

\section{Acknowledgements}

A. Abbas is grateful to the respondents, who completed our questionnaire and Dr. Amal K. Suleiman for providing statistical support. This study was funded by the Al-Mawred for Bank Operations Training.

\section{REFERENCES}

[1] A. Abbas, "Industrial Purchase Decision in Saudi Arabia: Dose Country of Origin Matters?” International Journal of Marketing Studies, Vol. 6, No. 1, 2014, pp. 344-361.

[2] M. Almossawi, "Bank Selection Criteria Employed by 
College Students in Bahrain: An Empirical Analysis,” International Journal of Bank Marketing, Vol. 19, No. 3, 2001, pp. 115-125.

http://dx.doi.org/10.1108/09604529610109774

[3] M. Mouawad and B. Kleiner, "New Developments in Customer Service Training,” Managing Service Quality, Vol. 6, No. 2, 1996, pp. 49-56. http://dx.doi.org/10.5539/ijbm.v6n12p222

[4] Saudi Arabian Monetary Agency, "Annual SAMA Report," 2013. http://www.sama-ksa.org/sites/samaen/pages/home.aspx

[5] A. Caruana, "Service Loyalty: The Effects of Service Quality and the Mediating Role of Customer Satisfaction," European Journal of Marketing, Vol. 36, No. 7, 2002, pp. 811-828.

http://dx.doi.org/10.1108/03090560210430818

[6] T. K. Panda, "Creating Customer Lifetime Value through Effective CRM in Financial Services Industry," Journal of Services Research, Vol. 2, No. 2, 2003, pp. 157-171.

[7] C. Lymperopoulos, L. E. Chaniotakis and M. Soureli, "The Importance of Service Quality in Bank Selection for Mortgage Loans,” Managing Service Quality, Vol. 16, No. 4, 2006, pp 365-379. http://dx.doi.org/10.1108/09604520610675702

[8] T. J. Levesque and G. H McDougall, "Determinants of Customer Satisfaction in Retail Banking," International Journal of Bank Marketing, Vol.14, No. 7, 1996, pp. 12-20. http://dx.doi.org/10.1108/02652329610151340

[9] J. Kish, "Before Your Customers Leave," Bank Marketing, Vol. 32, No. 2, 2000, p. 30.

[10] E. Duncan and G. Elliot, “Customer Service Quality and Financial Performance among Australian Retail Financial Institutions," Journal of Financial Services Marketing, Vol. 7, No. 1, 2002, pp. 25-41. http://dx.doi.org/10.1057/palgrave.fsm.4770070

[11] A. Fisher, "Winning the Battle for Customers," Journal of Financial Services Marketing, Vol. 6, No. 2, 2001, pp. 77-83. http://dx.doi.org/10.1057/palgrave.fsm.4770042

[12] B. O. Ehigie, "Correlates of Customer Loyalty to Their Bank: A Case Study in Nigeria,” International Journal of Bank Marketing, Vol. 24, No. 7, 2006, pp. 494-508. http://dx.doi.org/10.1108/02652320610712102

[13] A. Parasuraman, V. Zeithaml and L. Berry, "SERVQUAL: A Multiple-Item Scale for Measuring Consumer Perceptions of Service Quality,” Journal of Retailing Vol. 64, No. 1, 1988, pp. 12-40.

[14] I. Teich, "Holding on to Customers: The Bottom-Line Benefits of Relationship Building," Bank Marketing, Vol. 29, No. 2, 1997, pp. 12-13.

[15] P. Kotler, S. Ang, S. Leong and C. Tan, "Marketing Management: An Asian Perspective,” Prentice Hall Inc., Upper Saddle River, 1999.

[16] J. Bloemer and H. Kasper, "The Complex Relationship between Consumer Satisfaction and Brand Loyalty," Journal of Economic Psychology, Vol. 16, No. 2, 1995, pp. 311-329.

http://dx.doi.org/10.1016/0167-4870(95)00007-B
[17] V. Zeithaml, L. Berry and A. Parasuraman, "The Behavioral Consequences of Service Quality,” Journal of Marketing, Vol. 60, No. 2, 1996, pp. 31-46. http://dx.doi.org/10.2307/1251929

[18] M. Bitner, "Evaluating Service Encounters the Effects of Physical Surroundings and Employee Responses," Journal of Marketing, Vol. 52, No. 2, 1990, pp. 69-82. http://dx.doi.org/10.2307/1251871

[19] C. Ennew and M. Binks, “The Impact of Service Quality and Service Characteristics on Customer Retention: Small Businesses and Banks in the UK," British Journal of Management, Vol. 7, No. 3, 1996, pp. 219-230. http://dx.doi.org/10.1111/j.1467-8551.1996.tb00116.x

[20] U. Lehtinen and J. Lehtinen, "Service Quality-A Study of Dimensions,” Service Management Institute, Helsinki, 1982, pp.439-460.

[21] C. Lewis and B. Booms, "The Marketing Aspects of Service Quality,” In: Berry, L.L., Shostack, G. and Upah, G., Eds., Emerging Perspectives in Service Marketing, American Marketing Association, Chicago, 1983, pp. 99-107.

[22] C. Gronroos, “A service Quality Model and Its Marketing Implications,” European Journal of Marketing, Vol. 18, No. 4, 1984, pp. 36-44. http://dx.doi.org/10.1108/EUM0000000004784

[23] R. Lam and S. Burton, "SME Banking Loyalty (and Disloyalty): A Qualitative Study in Hong Kong," International Journal of Bank Marketing, Vol. 24, No. 1, 2006, pp. 37-52. http://dx.doi.org/10.1108/02652320610642335

[24] M. Lee and L. Cunningham, “A Cost/Benefit Approach to Understanding Service Loyalty," Journal of Services Marketing, Vol. 15, No. 2, 2001, pp. 113-130. http://dx.doi.org/10.1108/08876040110387917

[25] D. Wu, Z. Yang and L. Liang, "Using DEA-Neural Network Approach to Evaluate Branch Efficiency of a Large Canadian Bank,” Expert Systems with Applications, Vol. 31, No. 1, 2006, pp. 108-115. http://dx.doi.org/10.1016/j.eswa.2005.09.034

[26] R. Manandhar and J. Tang, "The Evaluation of Bank Branch Performance Using Data Envelopment Analysis. A Framework," Journal of High Technology Management Research, Vol. 13, No. 1, 2002, pp. 1-17. http://dx.doi.org/10.1016/S1047-8310(01)00045-1

[27] R. Johnston, “The Determinants of Service Quality: Satisfiers and Dissatisfies," International Journal of Service Industry Management, Vol. 6, No. 5, 1995, pp. 53-71. http://dx.doi.org/10.1108/09564239510101536

[28] J. McAlexander, D. Kaldenberg and H. Koenig, "Service Quality Measurement,” Marketing Health Services, Vol. 14, No. 3, 1994, pp. 34-40.

[29] A. Cowling and K. Newman, "Service Quality in Retail Bankng: The Experience of Two British Clearing Banks," International Journal of Bank Marketing, Vol. 14, No. 6, 1996, pp. 3-11. http://dx.doi.org/10.1108/02652329610130127

[30] G. Sureshchandar, C. Rajendran and R. Anantharaman, "Determinants of Customer-Perceived Service Quality: A Confirmatory Factor Analysis Approach,” Journal of Ser- 
vices Marketing, Vol. 16, No. 1, 2002, pp. 9-34. http://dx.doi.org/10.1108/08876040210419398

[31] A. Paswan, N. Spears, R. Hasty and G. Ganesh, "Search Quality in the Financial Services Industry: A Contingency Perspective,” Journal of Services Marketing, Vol. 18, No. 5, 2004, pp. 324-338. http://dx.doi.org/10.1108/08876040410548267

[32] N. Seth, S. Deshmukh and P. Vrat, "Service Quality Models: A Review," International Journal of Quality \& Reliability Management, Vol. 22, No. 9, 2005, pp. 913949. http://dx.doi.org/10.1108/02656710510625211

[33] R. Horstmann, "Customer Satisfaction and Loyalty: An Empirical Assessment in the Service Industry," Journal of Applied Management and Entrepreneurship, Vol. 4, No. 3, 1998, pp. 39-54.

[34] M. Zairi, "Managing Customer Dissatisfaction through Effective Complaint Management Systems," The TQM Magazine, Vol. 12, No. 5, 2000, pp. 331-335. http://dx.doi.org/10.1108/09544780010341932

[35] F. Mohsan, "Impact of Customer Satisfaction on Customer Loyalty and Intentions to Switch: Evidence from Banking Sector of Pakistan," International Journal of Academic Research in Business and Social Sciences, Vol. 2, No. 16, 2011.

[36] L. Tee, “The Effects of Service Quality, Customer Satisfaction on Re-patronage Intentions of Hotel Existing Customers," International Journal of Management and Administrative Sciences, Vol. 1, No. 8, 2012, pp. 60-73.

[37] Y. He and H. Song, “A Mediation Model of Tourists' Reprchase Intentions for Packaged Tour Services,” Journal of Travel Research, Vol. 47, No. 3, 2009, pp. 317-331. http://studentjournal.petra.ac.id/index.php/manajemen-per hotelan/article/view/949 http://dx.doi.org/10.1177/0047287508321206

[38] A. Agus, S. Barker and J. Kandampully, “An Exploratory Study of Service Quality in the Malaysian Public Service Sector," International Journal of Quality \& Reliability Management, Vol. 24, No. 2, 2007, pp. 177-190. http://dx.doi.org/10.1108/02656710710722284

[39] J. Hair, W. Black, B. Babin, R. Anderson and R. Tatham, "Multivariate Data Analysis," 6th Edition, Pearson Education, Inc., Upper Saddle River, 2006.

[40] J. Nunnally and I. Bernstein, "Psychometric Theory," McGraw-Hill, Inc., New York, 1994.

[41] R. Baron and D. Kenny, "The Moderator-Mediator Vari- able Distinction in Social Psychological Research: Conceptual, Strategic and Statistical Considerations," Journal of Personality and Social Psychology, Vol. 51, No. 6, 1986, pp. 1173-1182.

http://dx.doi.org/10.1037/0022-3514.51.6.1173

[42] N. Nguyen and G. Leblanc, "Corporate Image and Corporate Reputation in Customers' Retention Decisions in Services,” Journal of Retailing and Consumer Services, Vol. 8, No, 4, 2001, pp. 227-236. http://dx.doi.org/10.1016/S0969-6989(00)00029-1

[43] C. Bellini, G. Lunardi and J. Henrique, "Service quality in banks: Insights from the Brazilian Experience,” Journal of Internet Banking and Commerce, Vol. 10, No. 3, 2005, pp. 44-58.

[44] M. Jun, and S. H. Cai, "The Key Determinants of Internet Banking Service Quality: A Content Analysis,” International Journal of Bank Marketing, Vol. 19, No. 7, 2001, pp. 276-291. http://dx.doi.org/10.1108/02652320110409825

[45] A. Diaz and F. Ruiz, "The Consumer's Reaction to Delays in Service,” International Journal of Service Industry Management, Vol. 13, No. 2, 2002, pp. 118-140. http://dx.doi.org/10.1108/09564230210425331

[46] M. Joseph, Y. Sekhon, G. Stone and J. Tinson, “An Exploratory Study on the Use of Banking Technology in the UK. A Ranking of Importance of Selected Technology on Consumer Perception of Service Delivery Performance," International Journal of Bank Marketing, Vol. 23, No. 5, 2005, pp. 397-413. http://dx.doi.org/10.1108/02652320510612474

[47] N. Glaveli, E. Petridou, C. Liassides and C. Spathis, "Bank Service Quality: Evidence from Five Balkan Countries," Managing Service Quality, Vol. 16, No. 4, 2006, pp. 380394. http://dx.doi.org/10.1108/09604520610675711

[48] K. Butcher, B. Sparks and F. O’Callaghan, "Evaluative and Relational Influences on Service Loyalty,” International Journal of Service Industry Management, Vol. 12, No, 4, 2001, pp. 310-327. http://dx.doi.org/10.1108/09564230110405253

[49] N. Ndubisi, "A Structural Equation Modeling of the Antecedents of Relationship Quality in the Malaysia Banking Sector,” Journal of Financial Services Marketing, Vol. 11, No. 2, 2006, pp. 131-141. http://dx.doi.org/10.1057/palgrave.fsm.4760033 